\title{
Laportea decumana (Robx) Wedd. Herbal Endemic Potential from Indonesia: A Literature Review
}

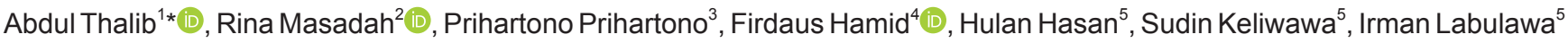 \\ ${ }^{1}$ Doctoral Student Program of Medicine, Medical Faculty, Hasanuddin University, Makassar, Indonesia; ${ }^{2}$ Department of \\ Pathology Anatomy, Hasanuddin University, Makassar, Indonesia; ${ }^{3}$ Department of Surgical Science, Hasanuddin University, \\ Makassar, Indonesia; ${ }^{4}$ Department of Microbiology, Hasanuddin University, Makassar, Indonesia; ${ }^{5}$ Department of Nursing, High \\ School of Health Science Pasapua Ambon, Ambon, Indonesia
}

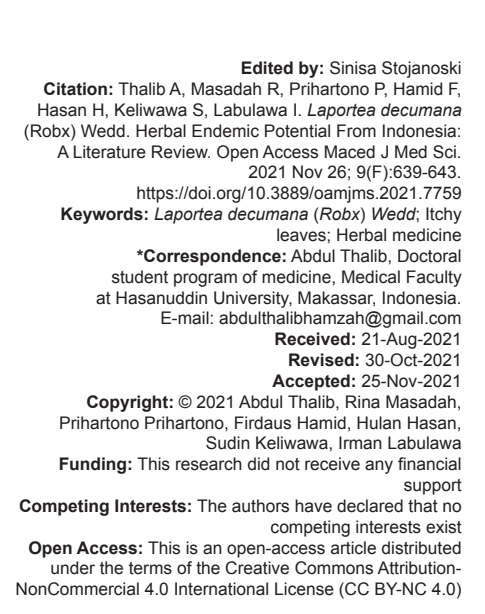

\begin{abstract}
BACKGROUND: Indonesia with its tropical rainforest and its endemic flora, namely, Laportea decumana (Robx) Wedd. which is used as a traditional medicine. If we want to adopt it in complementary of nursing therapy as herbal medicine, it must be proven on an evidence-based.

METHODS: The design in this study was a literature review article. Search for articles using relevant ones obtained from data based on Pubmed, Proquest, Ebsco, ScienceDirect, and Google Scholar in the span of the past 10 years (2011-2021) obtained 248 articles.

RESULTS: There are seven articles that are relevant and discuss their content and use in the health

CONCLUSION: L. decumana is found in Indonesia as well as in Papua New Guinea. L. decumana (Robx) Wedd. contains alkaloids, glycosides, steroids/triterpenoids, flavonoids, tannins, and saponins which have proven their antioxidant, antibacterial, analgesic, and cytotoxic activity.
\end{abstract}

\section{Introduction}

Indonesia with its tropical rainforests makes it rich in flora, although the area of Indonesia is only about $1.3 \%$ of the earth, but it ranks seventh in the world rich in flora with species reaching 20,000 species of which $40 \%$ are endemic plants of Indonesia [1].

The existence of endemic flora is very interesting to be developed especially in the field of health. Moreover, when people's interest in traditional medicine with the use of natural ingredients is increasing, this is shown by the increasing research on herbs in recent years. In the field of nursing, the use of herbs in the provision of nursing care especially in nursing interventions is legalized because it is part of complementary nursing therapy. There are four types of complementary therapies in nursing, namely, mindbody-spirit, manipulative and body-based therapy, biologically based therapies, and energy therapies, where herbal therapies are included in biologically based therapies [2].
Utilization of natural materials has basically been done since long ago where the knowledge is obtained through generations so that it is known as traditional medicine in the community. One of the traditional medicines that more used by people in the Eastern Indonesia, especially Papua and Maluku, is itchy leaves. Itchy leaves are scattered around the world as in Asia, Africa, [3] and Europe [4]. There are several types in Indonesia delivered Laportea interrupta (L.) Chew, [5], [6] Laportea aestuans (Linn.) Chew, [7] Dendrocnide peltate, [8] and Laportea decumana (Robx) [9].

L. decumana (Robx) is an endemic flora found in the Eastern Indonesia. People believe that L. decumana (Robx) is able to relieve aches, fatigue, relieve abdominal pain, and clean the baby's skin when used while pregnant. However, the use of traditional medicine needs to be proven scientifically because the lack of function and apology of traditional medicinal plants can actually turn into harmful ingredients. Therefore, this review will try to check the latest knowledge about $L$. decumana (Robx) with the aim of finding realistic use in the community. 


\section{Methods}

\section{Design}

This study is a literature review. Literature review is a survey whether it comes from scientific articles, books or from relevant sources that will be synthesis informative, critical, and useful for a particular topic [10], [11].

\section{Article criteria}

To focus the search for this review article, in this study made the criteria of inclusion: (1) Focus on L. decumana, (2) research in the field of health, (3) full texts, (4) published in the range of 2011-202, and (5) English language articles. The criteria of exclusion: (1) Just abstract, (2) incomplete text, and (3) double publication. The question in this study is how far is the testing of $L$. decumana (Robx) scientifically and its application in society?

\section{Article search}

In the search, the article uses the words "OR" and "AND" with the search word "Laportea AND Decumana" OR "Laportea AND Decumanum." The literature search using five data based: PubMed, ebsco, proquest, sciencedirect, and Google Scholar.

\section{Study selection}

In this article, 248 articles were identified from five database searches with descriptions of PubMed: 3, ebsco: 0, proquest: 0, sciencedirect: 0, and Google Scholar: 243, excluded articles that were double published. From these results, three articles were double published, 32 were excluded because they were not articles, and 191 were excluded because they were not in accordance with the research question. Of the 22 articles, 15 articles were excluded because they did not explain the use based on the content of $L$. decumana (robx.). The articles that were included were seven research articles.

The article selection process uses the prism method starting from Identification, Screening, Eligibility, until the Included article is obtained as presented in Figure 1.

\section{Results}

\section{Characteristic studies}

In this systematic review, there are seven articles that are included. This article was published from 2014 to 2020 . The research was conducted in Indonesia, one research conducted directly in humans and six other laboratory-based researches researches. Articles that meet the criteria are then summarized. The results of this summary are presented in a grid synthesis table as presented in Table 1.

\section{Discussion}

This systemic review aims to determine the scientific testing of $L$. decumana and its application. There are seven articles reviewed that discuss about the capabilities of $L$. decumana. $L$. decumana plant is not only found in Indonesia but also found in Papua New Guinea where it is still on land with the island of Papua [18], [19].

\section{Identification of the content of L. decumana}

Although in the community do not know the content of itchy leaves, they believe that the plant has extraordinary properties and knowledge is inherited hereditary that became part of the family medicinal plant [20]. Some studies discuss the content of L. decumana which states that the leaves of positive itching contain compounds of alkaloid group, steroidal glycosides/triterpenoids and negative for saponin, flavonoid, polyphenols, and tannins [15]. However, there is also research that explains that $L$. decumana (Roxb.) kuntze has flavonoids, tannins, and saponins [16].

\section{Identification of L. decumana capability}

\section{Analgesic}

Conventionally, people in Indonesia especially Eastern Indonesia have used it as a traditional medicine to relieve fatigue or as a tired reliever, some areas that use it such as in Maluku, Biak, and Depapre [14] Wulukubun Arso XIV [17]. L. decumana has also been used as an analgesic to overcome the problem of myalgia [12] besides it has also been made in the form of preparations and preparations that are water soluble preferred because it is easier to cleaned up [21]. In Papua, there are some itchy leaves commonly used by the community there to relieve aches such as $L$. decumana (Roxb.) Wedd, Laportea interrupta (L.) Chew, and Dendrocnide peltata (Blume) Miq [17], [22].

\section{Antioxidant}

The antioxidant ability of $L$. decumana is not widely known by the public so in its application is still very rare that is found in connection with its use as an antioxidant. There are two articles discussing the antioxidant capabilities of $L$. decumana where the 

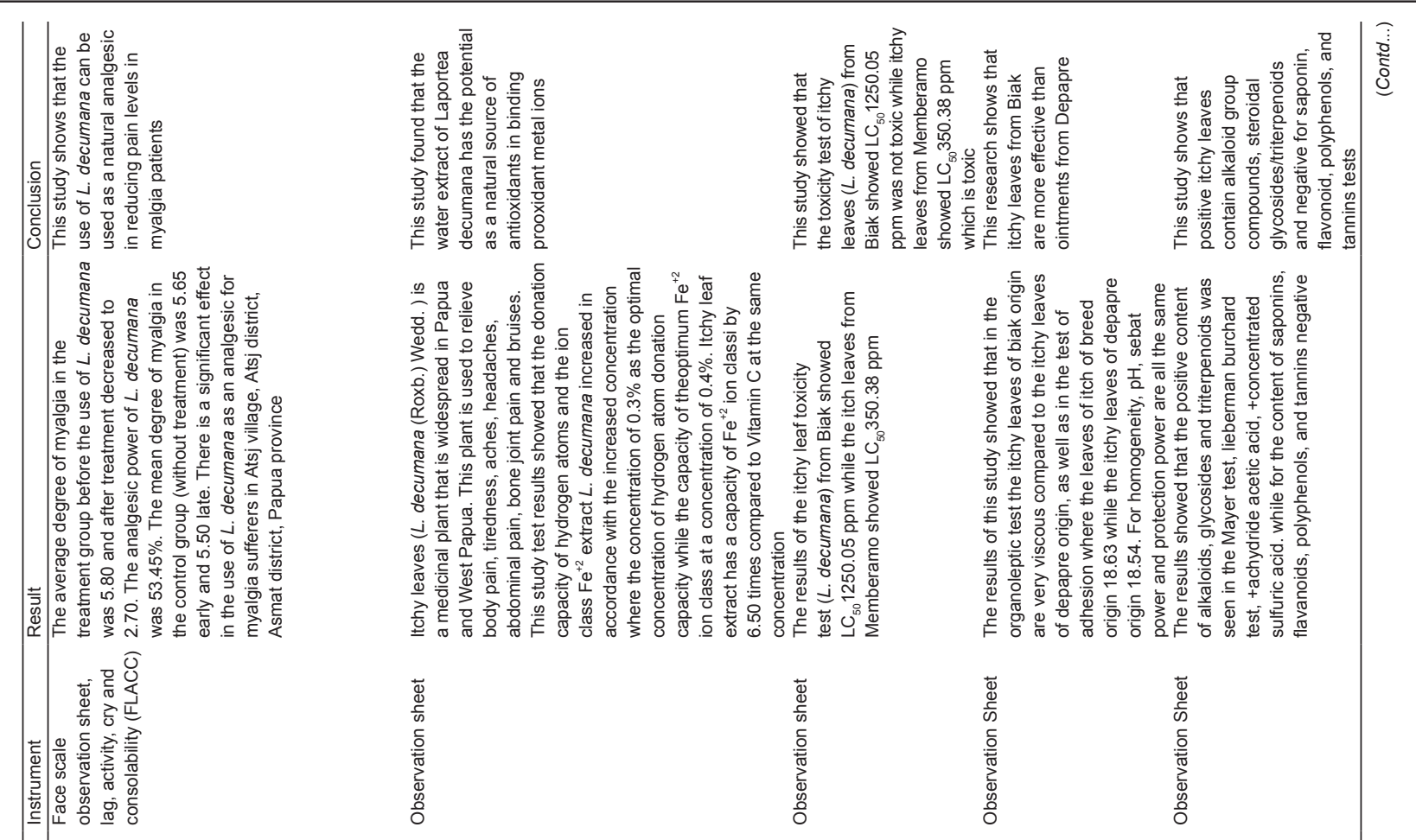

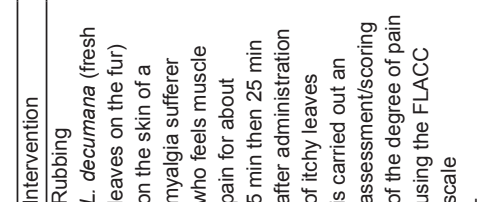

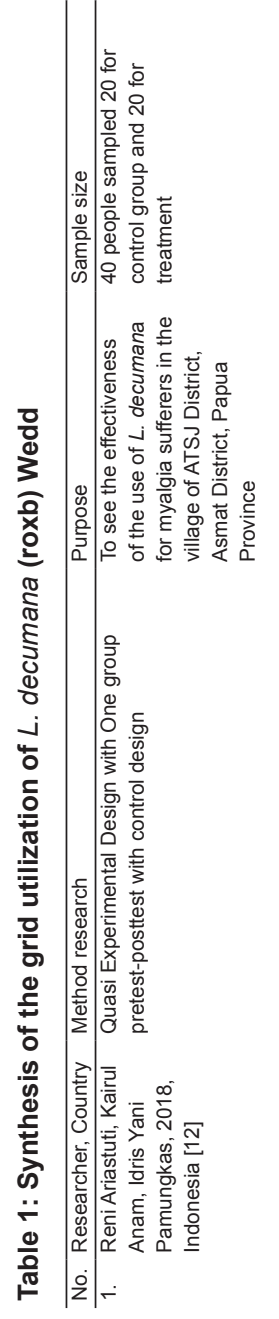

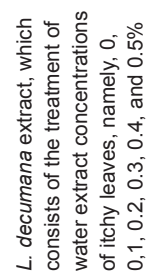
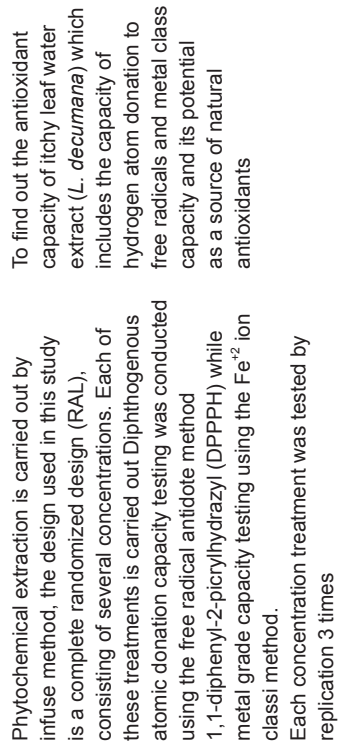

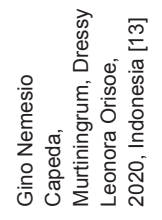

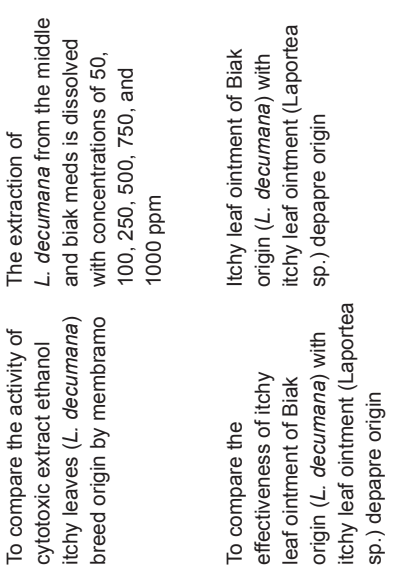

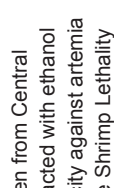

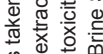

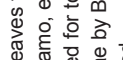

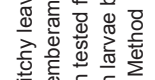

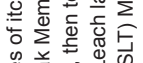

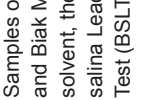

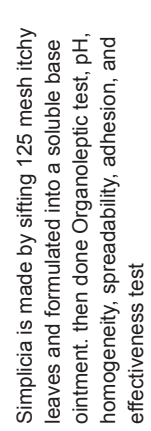

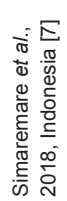

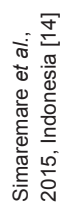

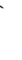




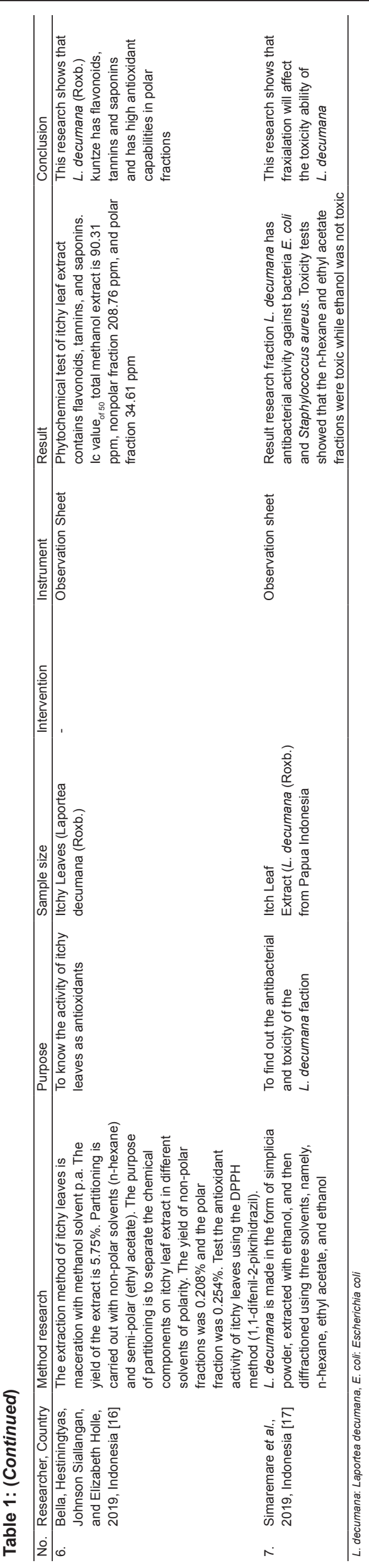

research is still in the scope of laboratory tests. The first research says that the water extract of $L$. decumana infused has the potential as a source of natural antioxidants in binding to metal ions that are proximal [13] with the content of flavonoids, tannins, and saponins which are high antioxidants in polar fractions [16].

\section{Antibacterial}

Onearticle discusses the antibacterial capabilities of the $L$. decumana faction where it has antibacterial activity against Escherichia coli and Staphylococcus aureus bacteria. The fraction is more effective as an antibacterial against the bacteria $S$. aureus.

\section{Cytotoxic}

There are two studies that discuss the cytotoxic capabilities of $L$. decumana. The research trying to compare itchy leaves that come from two different places where the results showed itchy leaves (L. decumana) from Biak showed $\mathrm{LC}_{50} 1250.05 \mathrm{ppm}$ is not toxic while itchy leaves from Memberamo show $\mathrm{LC}_{50} 350.38 \mathrm{ppm}$ which is toxic [14]. The technique of fractionation will also affect the ability of toxicity of L. decumana [9].

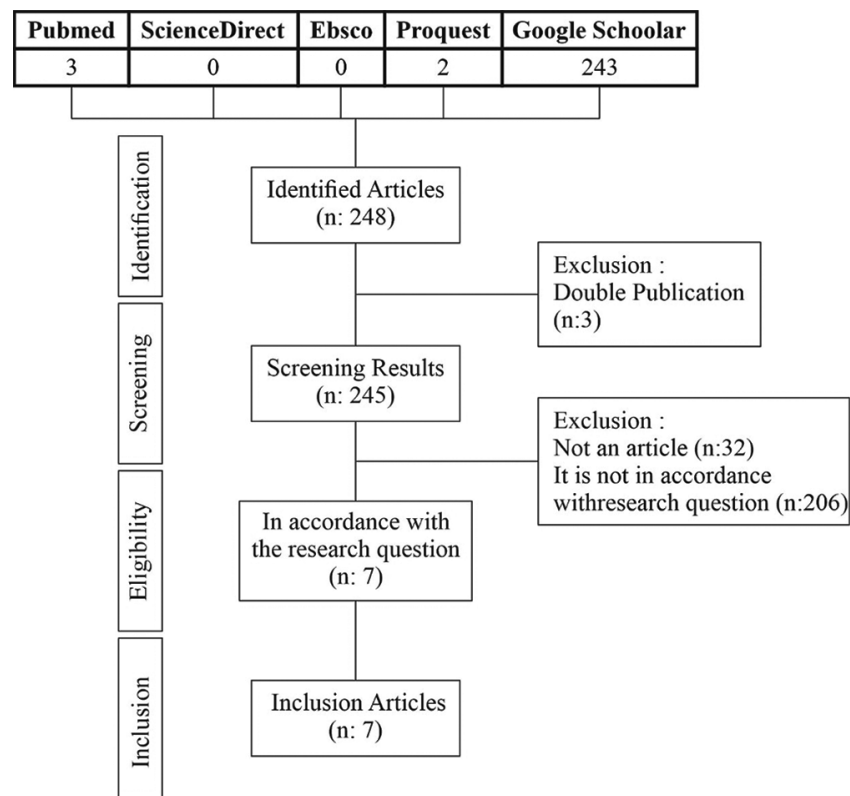

Figure 1: Flowchart of article selection and exclusion

\section{Conclusion}

L. decumana in addition to being in Indonesia is also in Papua New Guinea. L. decumana contains alkaloids, glycosides, steroids/triterpenoids, flavonoids, tannins, and saponins that have proven antioxidant activity, antibacterial, analgesic, and cytotoxic activity. 
However, no one has reported in detail about the compounds they contain specifically and as large as still in the laboratory test phase so it still needs to be done more in-depth research to get more detailed information from this plant.

\section{References}

1. Kusmana C, Hikmat A. Keanekaragaman hayati flora di Indonesia. J Pengelolaan Sumberd Alam dan Lingkung. 2015;5(2):187-98.

2. Lindquist R, Snyder M, Tracy MF. Complementary and Alternative Therapies in Nursing. $8^{\text {th }}$ ed. United States: Spinger Publishing Company; 2018. Available from: http://libgen.rs/book/ index.php?md5=6ED84FA3E80B033AEDB41C2F02263BD4. [Last accessed on 2021 Jun 25].

3. Omolola EO, Ogunlade OO, Salako AO. Phytochemical screening and antioxidant parameters data in prostatic rats fed with Laportea aestuans leaves. Data Brief. 2018;20:577-81. http://doi.org/10.1016/j.dib.2018.08.020

\section{PMid:30197914}

4. Mahlangeni NT, Moodley R, Jonnalagadda SB. Nutritional value, antioxidant and antidiabetic properties of nettles (Laportea alatipes and Obetia tenax). Sci Rep. 2020;10(1):1-7. http://doi. org/10.1038/s41598-020-67055-w

5. Safitri OM, Nurhamidah, Amir H. Potensi sitotoksik dan antibakteri ekstrak daun Laportea interrupta (L.) Chew (Jelatang Ayam) terhadap Staphylococcus aureus. J Pendidik IImu Kim. 2018;2(2):175-83.

6. Pertiwi KK. Aktivitas antibakteri herba daun gatal (Laportea interupta L. Chew) terhadap Staphylococcus aureus dan Escerichia coli. J Hestech Journal Heal Educ Sci Technol. 2019;2(1):43

7. Simaremare ES, Holle E, Gunawan E, Yabansabra YR, Octavia F, Pratiwi RD. Toxicity, antioxidant, analgesic and antiinflamantory of ethanol extracts of Laportea aestuans (Linn.) Chew. J Chem Pharm Res. 2018;10(5):16-23.

8. Mom SA, Langi MA, Kainde RP, Nurmawan W. Studi etnobotani tumbuhan daun gatal di kecamatan kwamkilama kabupaten mimika. E J Unsrat. 2015;6:1-8.

9. Simaremare ES, Gunawan E, Yarangga I, Satya MD, Yabansabra YR. Antibacterial and toxicity activities itchy leaves (Laportea decumana, Roxb. Wedd) extract. J Phys Conf Ser.

\section{0;1503(1):12041}

10. Bolderston A. Writing an effective literature review. J Med Imaging Radiat Sci. 2008;39(2):86-92.

11. Ramdhani A, Ramdhani MA, Amin AS. Writing a literature review research paper: A step-by-step approach. Int J Basic Appl Sci. 2014;3(1):47-56.

12. Ariastuti R, Anam K, Pamungkas IY. Efektifitas analgesik daun gatal (Laportea decumana) pada penderita myalgia di kampung ATSJ Distrik ATSJ Kabupaten Asmat Provinsi Papua. J Kebidanan. 2018;10(1):50-61.

13. Cepeda GN, Murtiningrum, Orisore DL. Kapasitas donas atom hidrogen dan kelasi metal ektrak daun gatal (Laportea decumana (Roxb.) Wedd.). J Sains dan Teknol Pangan. 2021;6(1):3603-12.

14. Simaremare ES, Holle E, Budi IM, Yabansabra Y. Analisis perbandingan efektivitas antinyeri salep daun gatal dari simplisia Laportea decumana dan Laportea sp. J Farm Indones. 2015;12(1):1-10.

15. Simaremare ES. Skrining fitokimia ekstrak etanol daun gatal (Laportea decumana (Roxb.) Wedd). Pharmacy. 2014;11(1):98-107.

16. Hestiningtyas B, Siallagan J, Holle E. Uji aktivitas ekstrak daun gatal (Laportea decumanum (Roxb.) Kuntze) sebagai antioksidan. AVOGADRO J Kim. 2019;3(1):1-5.

17. Simaremare ES, Pratiwi RD, Rusnaeni R, Gunawan E, Dirgantara S. Pemanfaatan tanaman daun gatal (Laportea decumana) Sebagai obat anti capek. J Pengabdian Pemberd Masyarakat. 2019;3(1):3027.

18. Jorim RY, Korape S, Legu W, Koch M, Barrows LR, Matainaho TK, et al. An ethnobotanical survey of medicinal plants used in the eastern highlands of Papua New Guinea. J Ethnobiol Ethnomed. 2012;8(1):1. http://doi.org/10.1186/1746-4269-8-47 PMid:23249544

19. Larson EC, Pond CD, Rai PP, Matainaho TK, Piskaut P, Franklin MR, et al. Traditional preparations and methanol extracts of medicinal plants from papua new guinea exhibit similar cytochrome p450 inhibition. Evid Based Complement Altern Med. 2016;2016:7869710. http://doi.org/10.1155/2016/7869710 PMid:27642356

20. Harefa D. Pemanfaatan hasil tanaman sebagai tanaman obat keluarga (TOGA). Madani Indones J Civ Soc. 2020;2(2):28-36.

21. Holle E, Simaremare ES, Yabansabra Y, Gunawan E, Ruban A. Uji mutu fisik formulasi salep daun gatal (Laportea decumana (Roxb.) Wedd,). J Farm Galen. 2016;3(2):16-23.

22. Simaremare ES, Uopmbin E, Gunawan E. Studi etnobotani daun gatal oleh masyarakat kiwirok papua. Pharmacy. 2019;16(1):4558. http://doi.org/10.1016/j.snb.2019.127013 